\title{
Growth and morphological responses of four helophyte species in an experimental water-depth gradient
}

\author{
Hugo Coops ${ }^{a, *}$, Fred W. B. van den Brink ${ }^{b}$, Gerard van der \\ Velde ${ }^{\mathrm{b}}$ \\ a Institute for Inland Water Management and Waste Water Treatment, P.O. Box 17, NL-8200 AA Lelystad, The \\ Netherlands \\ ${ }^{\circ}$ Department of Ecology, Laboratory for Aquatic Ecology, University of Nijmegen, NL-6525 ED Nijmegen, \\ The Netherlands
}

Accepted 18 January 1996

\begin{abstract}
The distribution on shorelines of four helophyte species (two gramineous species, viz. Phalaris arundinacea L. and Phragmites australis (Cav.) Trin. ex Steudel and two cyperacean species, viz. Scirpus maritimus L. and S. lacustris L.) was studied in relation to growth responses in the water-depth gradient. Stands of $S$. lacustris were found at lower depths relative to the mean water level (average fringe depth $69 \pm 19 \mathrm{~cm}$ ) than stands of Phragmites australis (av. $45 \pm 20 \mathrm{~cm}$ ), $S$. maritimus (av. $36 \pm 8 \mathrm{~cm}$ ) and Phalaris arundinacea (av. $25 \pm 8 \mathrm{~cm}$ ). The growth responses to a gradient of water depth were studied by planting the four species at five distinct water depths in outdoor basins, and determining morphological parameters and biomass distributions of the species grown for two consecutive years. The biomass of Phalaris arundinacea was reduced below $30 \mathrm{~cm}$ water depth, while Phragmites australis and $S$. maritimus showed reduced biomass at $80 \mathrm{~cm}$ water depth. $S$. lacustris showed no biomass reduction even at $80 \mathrm{~cm}$ water depth. An increased above-ground: below-ground biomass ratio in deeper water was demonstrated for each of the species under study; however, the modification of biomass distribution in the gramineous species occurred abruptly in very shallow water contrary to the cyperacean species. Mean basal stem diameter increased with water depth in all four species. Mean stem length increased with water depth in three of the four species. Stem elongation with increasing water depth was strongest in the cyperacean species. The gramineous species showed enhanced formation of adventitious roots at submerged nodes. The similarity of responses to water depth was greatest within each of the groups of gramineous and cyperacean species. The responses reflect the
\end{abstract}

\footnotetext{
* Corresponding author.
} 
zonation of the species along the water-depth gradient: S. lacustris in relatively deep water, Phragmites australis and S. maritimus in shallower water, and Phalaris arundinacea in very shallow water.

Keywords: Growth response; Helophytes; Morphological response; Phalaris; Phragmites; Scirpus; Water depth

\section{Introduction}

Emergent plants growing on river banks and lake shores are specially adapted to survive and grow in shallow water. The emergent vegetation of such habitats, which often consists of monospecific stands of tall monocotyledonous helophytes, is distributed over the water-depth gradient showing zonation between the species (Spence, 1982). Zonation patterns develop and are sustained because of the varying properties of the different species that enable them to establish, survive and colonize the water-depth gradient (Buttery and Lambert, 1965; Grace, 1987; Van der Valk and Welling, 1988). The potential for plastic modification of morphological traits facilitates the survival of the plants over a range of water depths. For instance, elongation of culms and increased shoot: root ratios have been shown to occur in water of increasing depth in various helophyte species (e.g. Haslam, 1970; Grace and Wetzel, 1981; Lieffers and Shay, 1981; Hultgren, 1989; Waters and Shay, 1990; Waters and Shay, 1992; Van den Brink et al., 1995).

Variation in plastic modification of morphological traits might be associated with differences between the species as regards flooding tolerance and competitive ability. Furthermore, the capacity for clone expansion over the water-depth gradient by means of rhizome growth might be a determinant of the establishment of zonation. The present study deals with the potential role of plastic growth characteristics of helophytes in establishing zonation over the water-depth gradient. It was focused on adult clones, as vegetative growth of the plants may be the common mode of propagation among helophytes (Bartley and Spence, 1987).

In a controlled growth experiment the following questions were addressed:

1. how do morphological characteristics and biomass distribution within plants of the species vary in relation to water depth;

2. are there similarities and/or differences in water-depth response between the species; and

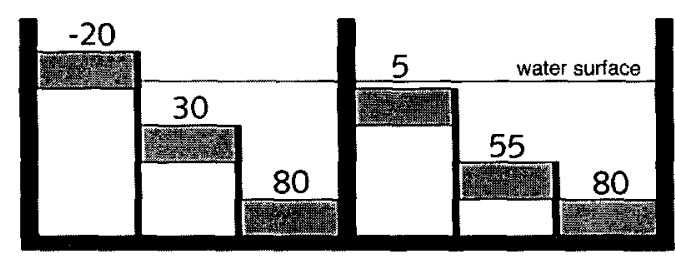

Fig. 1. Schematic cross-section of the basins used in the experiment, showing the different water depths of benches on which helophytes were planted. 
3. can the zonation of the species along the water-depth gradient be explained by growth modifications?

Four helophyte species common in riparian environments in The Netherlands were selected, two of which were gramineous species, viz. Phalaris arundinacea L. and Phragmites australis (Cav.) Trin. ex Steudel, while the other two were cyperacean species, viz. Scirpus maritimus L. and S. lacustris L.

\section{Materials and methods}

Field measurements were conducted in helophyte-dominated vegetation belts bordering the Nieuwe Merwede river branch $\left(51^{\circ} 47^{\prime} \mathrm{N} 4^{\circ} 45^{\prime} \mathrm{E}\right)$. This estuarine section of the river Rhine was originally a freshwater tidal area (mean tidal amplitude c. $2 \mathrm{~m}$ ), which has at present a strongly reduced tidal amplitude (mean tidal amplitude c. $0.3 \mathrm{~m}$ ). The elevations (in $\mathrm{cm}$ above sea level) of the lower fringes of a number of monospecific stands of Phalaris arundinacea $(n=9)$, Phragmites australis $(n=28)$, Scirpus maritimus $(n=5)$, and $S$. lacustris $(n=13)$ were determined and related to the mean water level, which was derived from hydrological data obtained from a local monitoring station (Deeneplaat, $51^{\circ} 44^{\prime} \mathrm{N} 4^{\circ} 43^{\prime} \mathrm{E}$ ), using a 20 -year series of water-level recordings at $10 \mathrm{~min}$ intervals. A nonparametric test (Kolmogorov-Smirnov test, $P<0.05$ ) was used to test between-species differences in fringe depth.

Four $4 \mathrm{~m} \times 4 \mathrm{~m} \times 1.5 \mathrm{~m}$ outdoor basins (concrete, covered with bitumen), situated at Dordrecht, in the vicinity of the Nieuwe Merwede River, were used in a growth experiment at various water depths (Fig. 1). In each basin, two $4 \mathrm{~m} \times 1 \mathrm{~m} \times 0.3 \mathrm{~m}$ wooden benches were placed at a number of water depths; each water depth was duplicated. The water-level in each basin could be regulated by means of a pumping installation. The basins were filled with river water; throughout the experiment, light could penetrate down to the bottom of the basins due to the still conditions of the water. Mean monthly air temperatures in 1990 were between $8^{\circ} \mathrm{C}$ in January and $24^{\circ} \mathrm{C}$ in August; the total global irradiation was $39.10^{4} \mathrm{~J} \mathrm{~cm}^{-2}$ in 1990 . The water level was kept constant $( \pm 5 \mathrm{~cm})$ at the level where the bench surfaces were at $20 \mathrm{~cm}$ above the water level, and at $5 \mathrm{~cm}, 30 \mathrm{~cm}, 55 \mathrm{~cm}$, and $80 \mathrm{~cm}$ water depth, respectively. Each bench was filled with a $30 \mathrm{~cm}$ layer of coarse sand (organic matter content $<1 \%$, median grain size $400 \mu \mathrm{m}$, silt (fraction $<16 \mu \mathrm{m}$ ) $6.1 \%$, total nitrogen $70 \mathrm{mg} \mathrm{kg}^{-1}$, total phosphorus $100 \mathrm{mg} \mathrm{kg}^{-1}$ ).

Approximately $10 \mathrm{~cm}$ long rhizome sections of Phalaris arundinacea, Phragmites australis, S. maritimus, and S. lacustris (Fig. 2), bearing young shoots and roots, were harvested at the field locations in March 1989. All species were raised until early May 1989 in a shallowly flooded pond (water level $\pm 1 \mathrm{~cm}$ above soil surface). On 2 May 1989 they were planted on the benches; 16 rhizome segments were planted on each bench in a grid in an $1 \mathrm{~m} \times 1 \mathrm{~m}$ quadrat, spaced $10 \mathrm{~cm}$ apart. The rhizomes were planted $\pm 10 \mathrm{~cm}$ below the soil surface, each provided with a $7 \mathrm{~g}$ tablet of slow-release fertilizer (Osmocote, $17 \% \mathrm{~N}, 1.6 \% \mathrm{P}, 8.7 \% \mathrm{~K}$ ).

In July 1990, maximum distances of rhizome runners outside the planted areas were measured before the runners were cut off in order to prevent intermixing of the species. 


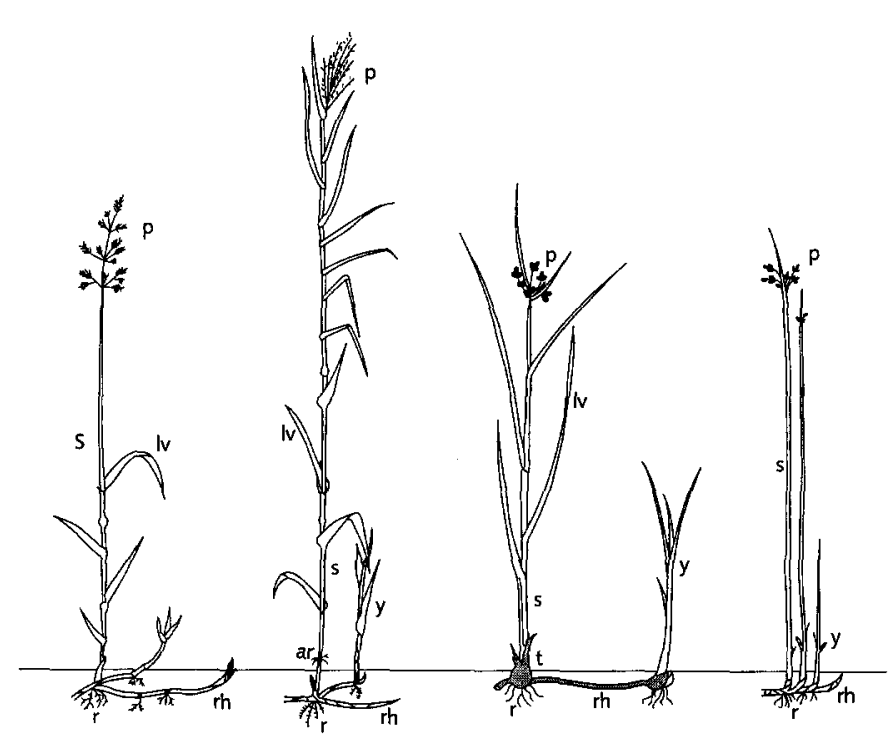

Fig. 2. Habitus of (a) Phalaris arundinacea, (b) Phragmites australis, (c) Scirpus maritimus, and (d) $S$. lacustris. $r$, roots; $r h$, rhizome runner; $t$, rhizome tuber; $a r$, adventitious roots; $s$, stem; $y$, young stem; $l v$, leaves; $p$, panicle.

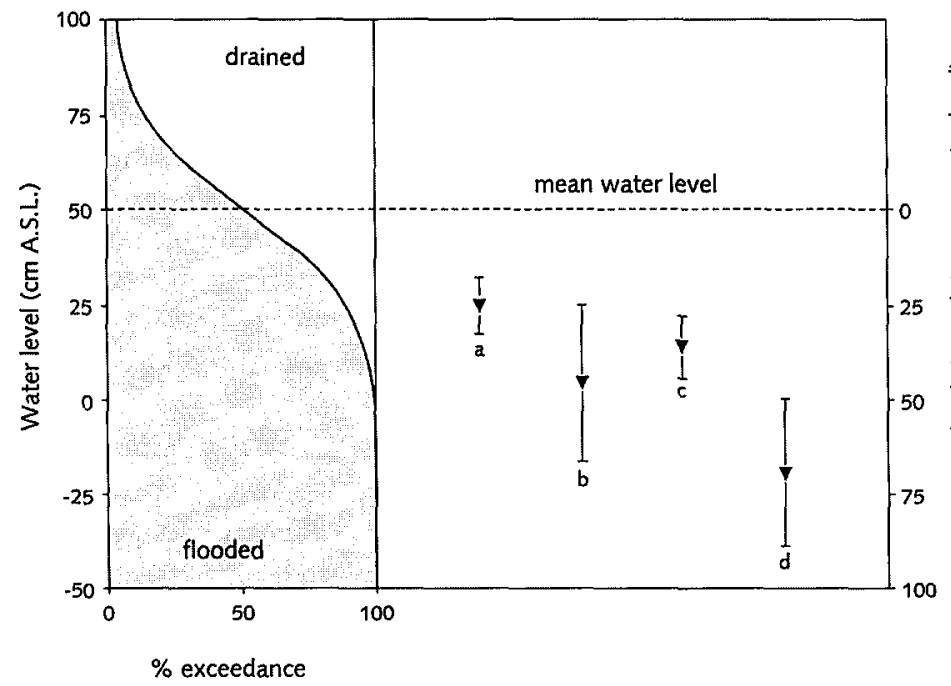

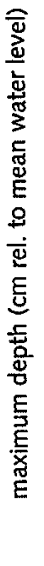

Fig. 3. Fringe depths ( $\nabla$, mean fringe depth in $\mathrm{cm}$ above sea level ( \pm s.d.)) of stands of (a) Phalaris arundinacea, (b) Phragmites australis, (c) Scirpus maritimus, and (d) S. lacustris along the River Nieuwe Merwede. The water-level exceedance curve for the area in which the locations were situated is shown on the left part, indicating the long-term percentage of time during which a particular location is flooded. 
Relationships between water depth and rhizome expansion were determined by linear regression; differences between the species were tested using a $t$-test.

Above-ground and below-ground parts in two separate $40 \mathrm{~m} \times 40 \mathrm{~cm}$ plots inside each quadrat were harvested separately in August 1990. Stem numbers, and for each individual stem the length (length from stem base to tip of highest leaf), diameter (measured at stem base), number of leaves, and number of nodes with adventitious roots were determined. After sieving and rinsing to remove sand, the dry weight biomass of below-ground parts (roots and rhizomes separately) and above-ground parts (stems, leaves and panicles separately) were determined after drying for $48 \mathrm{~h}$ at $105^{\circ} \mathrm{C}$.

For each treatment, ten to 20 rhizomes bearing young offshoots were collected on 26 March 1991. Mean length and basal diameter of young stems were determined, as well as rhizome diameter. The proportion of rhizome gas space (in the gramineous species) and rhizome stele (in the cyperacean species) relative to the total cross-sectional area were determined after microscopic measurement of cross-sectional areas of rhizomes.

As no effects of the different tanks could be detected for any of the parameters measured, data from all plots at a particular water depth were pooled. The effects of water depth on several growth parameters (log-transformed shoot density, stem length, and biomass) were tested separately using an $F$-test, followed by comparison of means (test of least significant difference, $P<0.05$ ).

Cluster analysis (average linkage method with squared Euclidean distances as a similarity index) of the species growing at various water depths was performed, using fifteen morphological parameters measured for the stands of each of the species at different water depths (stem density, number of nodes with adventitious roots, stem length and basal stem width early (March 1991) and late (August 1990) in the growth season, maximum stem length, rhizome expansion distance, rhizome diameter, cross-sectional area of the gas space in the rhizome, cross-sectional area of the rhizome stele, rhizome bud or tuber diameter, above-ground biomass, below-ground biomass, and above-ground: below-ground biomass ratio).

\section{Results}

The helophyte stands showed a broad overlap in distribution over the water-depth gradient relative to the mean water level in the Nieuwe Merwede River branch, but the differences between the four species in the maximum water depth of stand fringes were highly significant $(P<0.001)$ (Fig. 3). Stands of Phalaris arundinacea (average $25 \pm 8$ $\mathrm{cm}$, max. $35 \mathrm{~cm}$ water depth) and $S$. maritimus (average $36 \pm 8 \mathrm{~cm}$, max. $45 \mathrm{~cm}$ water depth) had expanded into relatively shallow water only. Phragmites australis showed an intermediate range (average $45 \pm 20 \mathrm{~cm}, \max .70 \mathrm{~cm}$ water depth), while S. lacustris fringes were generally found in deeper water than the other three species (average $69 \pm 19 \mathrm{~cm}$, max. $100 \mathrm{~cm}$ water depth).

The parameters significantly responding to water depth in the mesocosm experiment were not identical for the four species. Stem densities gradually decreased below $5 \mathrm{~cm}$ water depth in Phalaris arundinacea and S. lacustris. The stem densities showed an irregular pattern over the water-depth gradient in Phragmites australis and S. mar- 

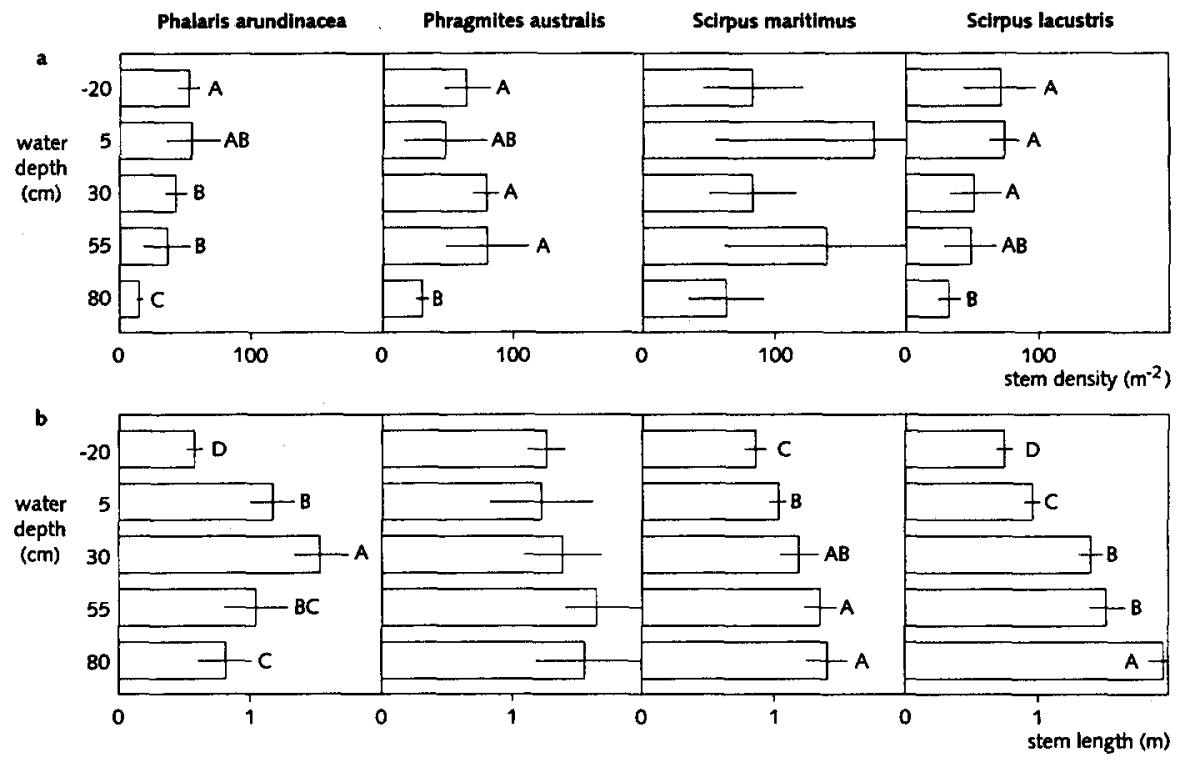

Fig. 4. Effects of water depth in the experimental water-depth gradient on mean stem densities $\left(\mathrm{m}^{-2} \pm 2 \mathrm{SE}\right)$ (a) and mean stem lengths ( $\pm 2 \mathrm{SE}$ ) (b) of Phalaris arundinacea, Phragmites australis, Scirpus maritimus, and $S$. lacustris. Different symbols indicate significantly different mean values.

itimus. Stem densities were small for all species at a water depth of $80 \mathrm{~cm}$ (Fig. 4). Both $S$. lacustris and $S$. maritimus showed a highly significant, increasing elongation of stems towards deeper water. In contrast, increasing mean stem lengths in Phalaris arundinacea occurred until a water depth of $30 \mathrm{~cm}$, while Phragmites australis showed no
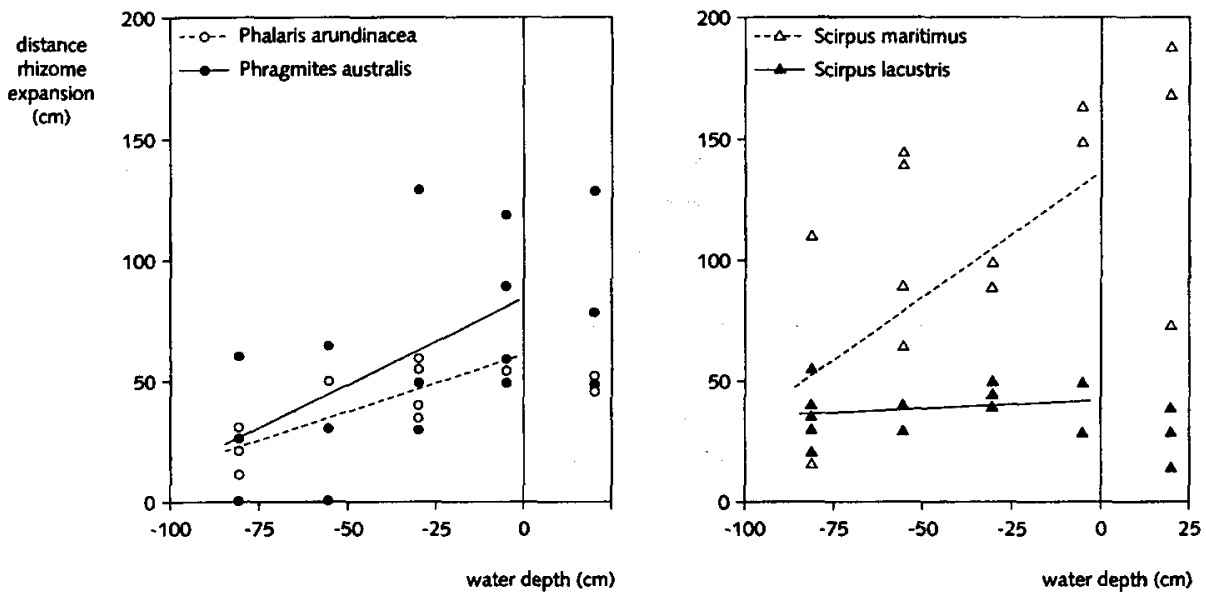

Fig. 5. Vegetative rhizome expansion from the planting edge, in relation to water depth in the experimental water-depth gradient. 

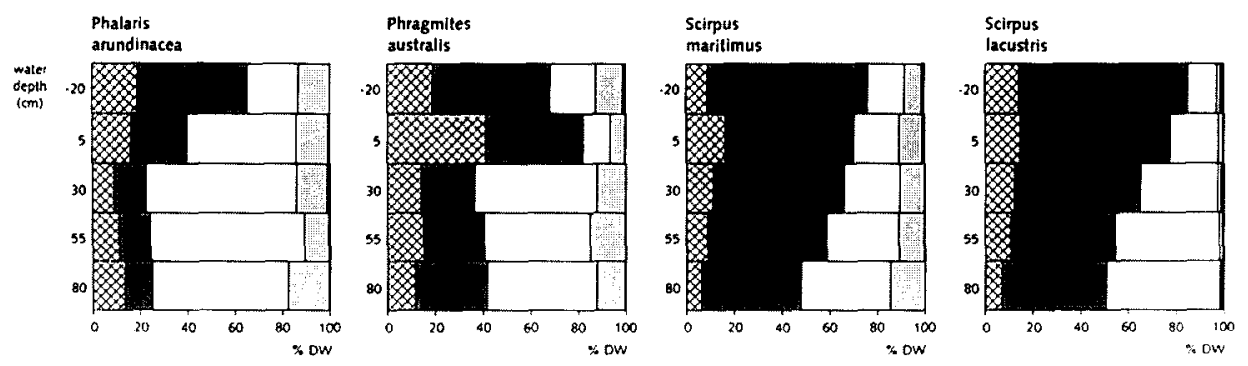

奴双 roots

thizomes

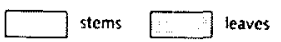

panicles

Fig. 6. Distribution of plant biomass in Phalaris arundinacea, Phragmites australis, Scirpus maritimus, and $S$. lacustris grown at different positions in the water-depth gradient: percentage of total dry weight in roots, rhizomes, stems (including leaf sheaths), leaves, and panicles, respectively.

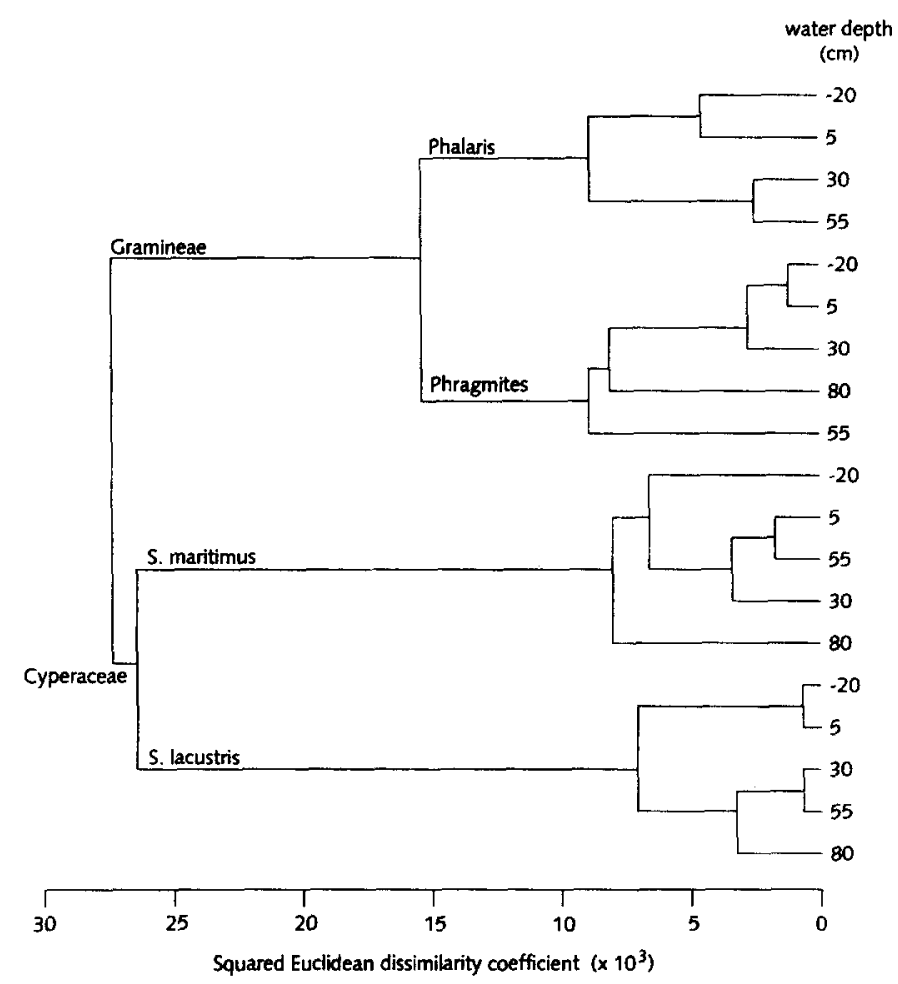

Fig. 7. Between-group average linkage clustering (squared Euclidean distances) of the four helophyte species at different water depths, using the values of 12 morphological parameters of adult plants (shoot density, adventitious roots, stem length in March and August, basal stem width in March and August, leaf area index, rhizome expansion, rhizome cross-sectional diameter, rhizome gas space cross-sectional area, rhizome stele cross-sectional area, rhizome tuber diameter). 


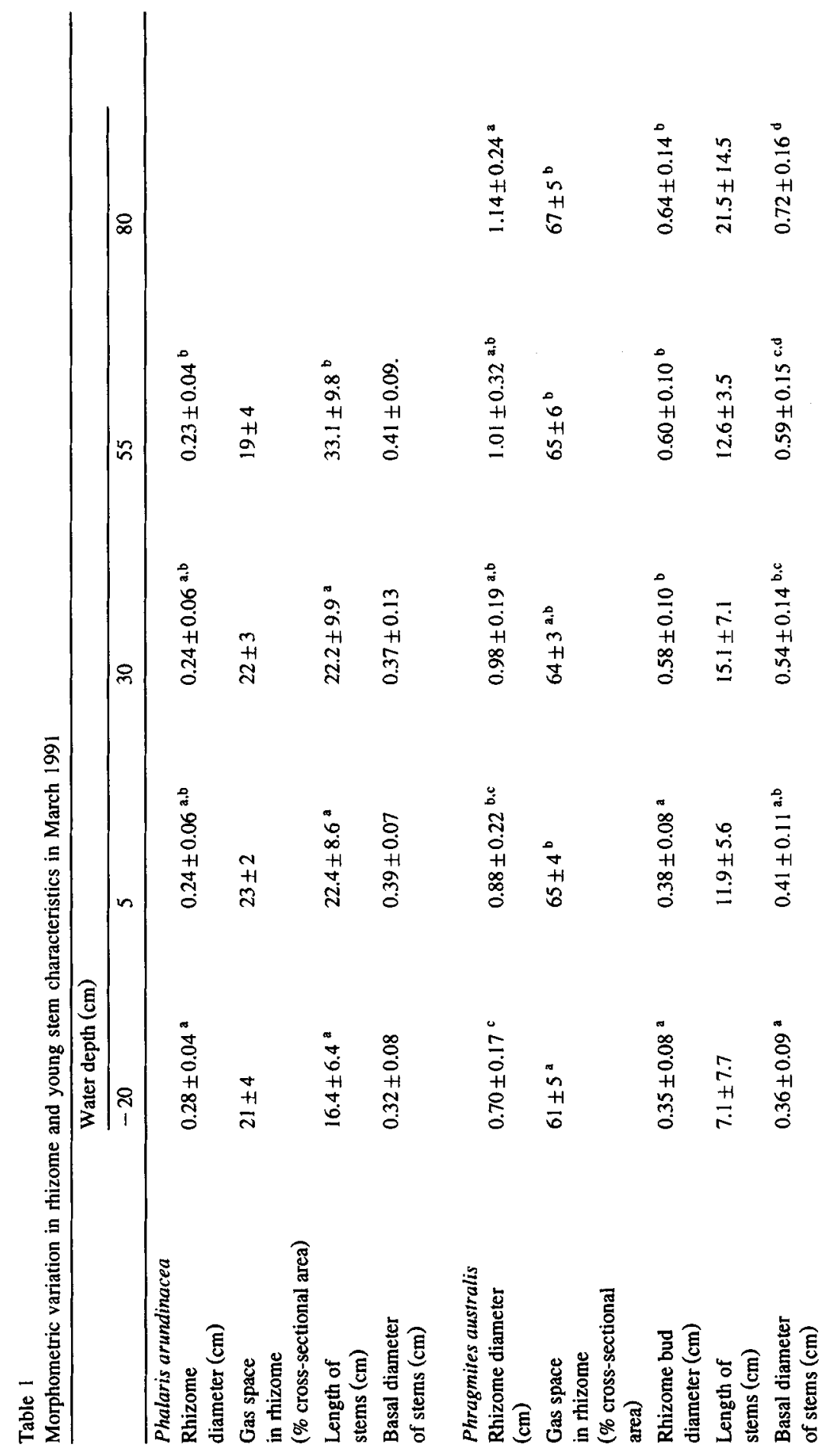




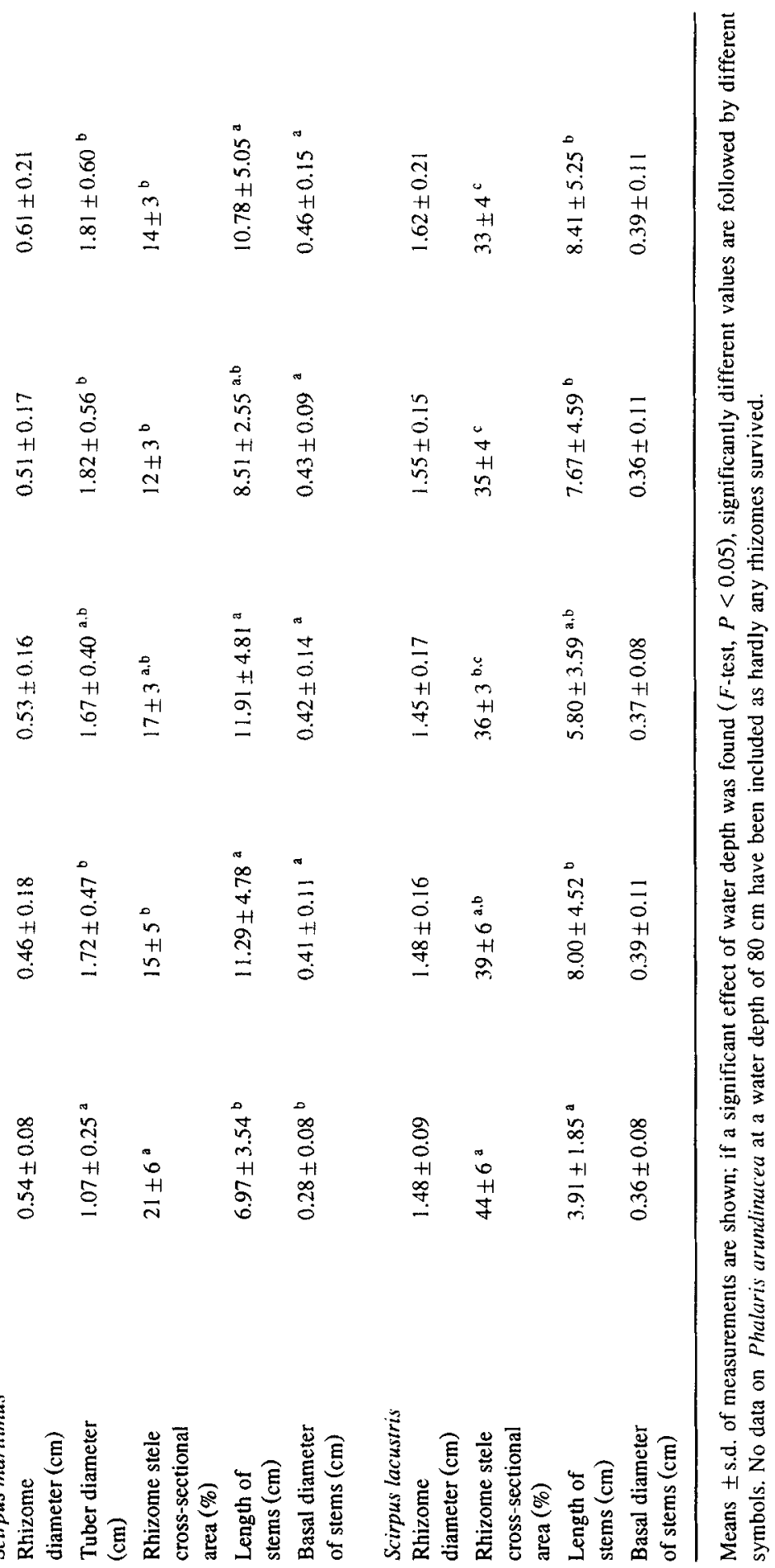


pronounced changes of mean stem length over the water depth gradient (Fig. 4). Basal stem diameter showed a major increase in deeper water in both Scirpus species, but not in the gramineous species (Table 1). The mean number of stem nodes bearing adventitious roots increased for the gramineous species Phalaris arundinacea and Phragmites australis; no adventitious roots were formed by the cyperacean species.

Rhizome diameters of Phalaris arundinacea in early spring showed some decrease with increasing water depth, while at the same time the relative amount of gas space in the rhizome remained constant over the water-depth gradient (Table 1). In contrast, both the external diameter of the rhizome and the central cavity of Phragmites australis increased with increasing water depth. The proportion of rhizome stele tissue decreased in deeper water in the Scirpus species, whereas the rhizome diameter did not show a significant response to water depth.

The horizontal expansion of rhizomes by means of underground rhizome growth showed a significantly negative relationship with water depth for three of the four species (Phalaris arundinacea: rhizome expansion $=-0.48$ depth $+60.27(\mathrm{~cm}), P=$ 0.0001; Phragmites australis: rhizome expansion $=-0.74$ depth $+84.42(\mathrm{~cm}), P=$ 0.026; Scirpus maritimus: rhizome expansion $=-1.06$ depth $+136.56(\mathrm{~cm}), P=0.017)$. Rhizome expansion of $S$. lacustris did not significantly increase or decrease with depth

Table 2

Above-ground and below-ground biomasses $\left(\mathrm{g} \mathrm{m}^{-2}\right)$, above-ground : below-ground biomass ratios, and numbers of nodes bearing adventitious roots of the helophyte species at different water depths in August 1990

\begin{tabular}{|c|c|c|c|c|c|}
\hline & \multicolumn{5}{|c|}{ Water depth $(\mathrm{cm})$} \\
\hline & -20 & 5 & 30 & 55 & 80 \\
\hline \multicolumn{6}{|c|}{ Above-ground biomass $\left(\mathrm{g} \mathrm{m}^{-2}\right)$} \\
\hline Phalaris arundinacea & $794 \pm 164^{a}$ & $1521 \pm 347^{a}$ & $1721 \pm 483^{a}$ & $908 \pm 275^{a}$ & $248 \pm 50^{b}$ \\
\hline Phragmites australis & $1235 \pm 483$ & $835 \pm 221$ & $2133 \pm 907$ & $4352 \pm 969$ & $830 \pm 326$ \\
\hline Scirpus maritimus & $168 \pm 35^{b}$ & $516 \pm 87^{a}$ & $558 \pm 49^{a}$ & $805 \pm 224^{a}$ & $463 \pm 95^{a}$ \\
\hline Scirpus lacustris & $455 \pm 81^{c}$ & $742 \pm 70^{b, c}$ & $1076 \pm 274^{\mathrm{a}, \mathrm{b}}$ & $1588 \pm 55^{\mathrm{a}}$ & $1576 \pm 217^{\mathrm{a}}$ \\
\hline \multicolumn{6}{|c|}{ Below-ground biomass $\left(\mathrm{g} \mathrm{m}^{-2}\right)$} \\
\hline Phalaris arundinacea & $1352 \pm 74^{a}$ & $990 \pm 124^{a, b}$ & $494 \pm 47^{b, c}$ & $289 \pm 52^{c}$ & $76 \pm 28^{d}$ \\
\hline Phragmites australis & $1995 \pm 261$ & $2122 \pm 1791$ & $1602 \pm 595$ & $1878 \pm 347$ & $1079 \pm 342$ \\
\hline Scirpus maritimus & $517 \pm 92^{b}$ & $1207 \pm 116^{a}$ & $1073 \pm 181^{a}$ & $1126 \pm 97^{a}$ & $391 \pm 108^{b}$ \\
\hline Scirpus lacustris & $2177 \pm 458$ & $2190 \pm 87$ & $1967 \pm 688$ & $1897 \pm 128$ & $1598 \pm 264$ \\
\hline \multicolumn{6}{|c|}{ Above-ground: below-ground biomass ratio } \\
\hline Phalaris arundinacea & $0.58 \pm 0.16$ & $1.50 \pm 0.49$ & $3.39 \pm 1.34$ & $3.06 \pm 1.10$ & $5.11 \pm 2.84$ \\
\hline Phragmites australis & $0.59 \pm 0.30$ & $1.67 \pm 2.14$ & $1.30 \pm 0.12$ & $2.30 \pm 0.13$ & $0.96 \pm 0.86$ \\
\hline Scirpus maritimus & $0.34 \pm 0.11$ & $0.43 \pm 0.10$ & $0.55 \pm 0.12$ & $0.71 \pm 0.34$ & $1.51 \pm 1.07$ \\
\hline Scirpus lacustris & $0.21 \pm 0.05$ & $0.34 \pm 0.08$ & $0.58 \pm 0.09$ & $0.84 \pm 0.12$ & $1.11 \pm 0.53$ \\
\hline \multicolumn{6}{|c|}{ Number of nodes with adventitious roots } \\
\hline Phalaris arundinacea & $0.0 \pm 0.0$ & $0.3 \pm 0.6$ & $2.4 \pm 1.6$ & $3.2 \pm 2.2$ & $5.9 \pm 6.2$ \\
\hline Phragmites australis & $0.3 \pm 0.5$ & $0.3 \pm 0.5$ & $0.7 \pm 0.6$ & $0.8 \pm 0.9$ & $1.7 \pm 2.0$ \\
\hline
\end{tabular}

Means \pm s.d. of measurements are shown; if a significant effect of water depth was found ( $F$-test, $P<0.05$ ), significantly different values are followed by different symbols. 
(rhizome expansion $=-0.09$ depth $+43.46(\mathrm{~cm}), P=0.37$ ). The latter slope was significantly smaller ( $t$-test, $P<0.05$ ) than the slopes of the other three species (Fig. 5).

Although total biomass varied considerably within each treatment, it was significantly lower at a water depth of $80 \mathrm{~cm}$ than at all other levels for Phalaris arundinacea, Phragmites australis, and S. maritimus, but not for S. lacustris. Above-ground (divided over stems, leaves and panicles) and below-ground (divided over rhizomes and roots) dry weight biomasses after harvest in September 1990 are presented in Table 2.

The ratios of above-ground: below-ground biomass of the stands were significantly affected by both water depth $(F=7.14, P<0.001)$ and species $(F=20.40, P<0.001)$. In all four species, the major part of the biomass was formed by rhizomes when growing exposed or in very shallow water, whereas water an increasing proportion of the biomass was present in above-ground parts in deeper water (Fig. 6). However, the increase of the above-ground: below-ground biomass ratio with increasing water depth was abrupt for Phalaris arundinacea and Phragmites australis but continuous for Scirpus spp.

Clustering of species at various depths on the basis of fifteen morphological traits demonstrates a major division between the two gramineous and the two cyperacean species. The similarity between plants growing at different water depths decreased with increasing difference in depth (Fig. 7).

\section{Discussion and conclusions}

Water depth had a pronounced effect on growth and morphological characteristics of the four helophyte species. Apparently, stress from growing at a water depth of $80 \mathrm{~cm}$ occurred in three of the four species studied, judging from the decreased total biomass of the plants. The biomass distribution within the plants varied with water depth, while various modifications of morphological traits of the species occurred over the water-depth gradient. A high potential for plastic adjustment of morphological and physiological characteristics to increased water depth is common among helophytes (Hejný and Hroudová, 1987). Elongation of stems helps to maintain photosynthetically active leaf and stem surface area (Lieffers and Shay, 1981; Coops and Smit, 1991). Stem lengths appear to increase towards $80 \mathrm{~cm}$ water depth in $S$. lacustris and $S$. maritimus, but in the two gramineous species the greatest mean lengths were found at water depths of 30 $\mathrm{cm}$ (Phalaris arundinacea) and $55 \mathrm{~cm}$ (Phragmites australis), respectively. Contrary to the other three species, $S$. lacustris maintained a high biomass production in $80 \mathrm{~cm}$ of water, as was also recorded by Seidel (1955).

An increased proportion of aerenchymatous tissue in shoots and roots and formation of adventitious roots, but also physiological adjustment, are common responses of wetland plant species to increased water depth (Steinmann and Brändle, 1984; Brändle and Crawford, 1987; Justin and Armstrong, 1987; McKee et al., 1989; Armstrong et al., 1994). Gas transport capacity is regulated by diffusion characteristics of the stem and rhizomes (Armstrong, 1979; Justin and Armstrong, 1987). The hollow central cylinder in Phragmites australis and Phalaris arundinacea stems and rhizomes, however, did not show a pronounced response to increased water depth. The increased proportion of cortical tissue in the rhizomes of Scirpus spp. indicates an adjustment towards more 
effective gas diffusion, as the gas-diffusion rate in rhizome cortex tissue is higher than in the central stele (Justin and Armstrong, 1987). In the gramineous species, adventitious roots are formed at the lower stem nodes in the inundated part of the plant. Under the potentially unfavourable conditions for root growth in inundated soils (low redox potential, toxic state of several ions), adventitious root formation might be advantageous to the plant by facilitating nutrient uptake from the water column rather than from the rhizosphere (Rodewald-Rudescu, 1974; Lefor, 1987).

The extremely high plasticity of $S$. lacustris with respect to shoot growth in relatively deep water might result in avoidance of competitive interactions with other helophytes. It may find a refugium below the water depth where other helophyte species can grow vigorously. Colonization of lower parts of banks occurs by means of rhizome expansion. Phalaris arundinacea, Phragmites australis and S. maritimus appeared to spread relatively fast in shallow water, but much slower when the water depth increases, while $S$. lacustris clones showed an equal, relatively slow, expansion rate over the entire depth gradient.

In contrast to the observation that water-depth penetration was clearly different for stands of the four species under natural conditions, all four species survived over the entire water-depth gradient in the experiment, up to the water depth of $80 \mathrm{~cm}$. The lack of difference in survival may be due either to the absence of interspecific competition in the experiment, or to the relatively short period over which the experiment was run (two growth seasons). In a longer experiment, exhaustion of nutrient resources would probably have led to more pronounced differences between the species as regards their survival in deeper water. Squires and Van der Valk (1992) explained a similar disagreement as being due to the short duration of the experiment relative to the vegetation processes in the field. Stress from growing in deep water might at length result in the elimination of clones at a particular water depth. However, clonal plants may persist for years at unfavourable positions in the water-depth gradient; for example, $S$. maritimus tubers remain viable in the sediment while being flooded by deep water for several years (Squires and Van der Valk, 1992). The allocation of reserves to the rhizome is reduced in plants growing in deep water, resulting in poor regeneration in the next growth season.

Furthermore, elimination of stands from particular water depths may be the result of competitive exclusion (Grace and Wetzel, 1981; Grace, 1987). The result of competitive interactions may vary with water depth, due to differences in the relative performance of the competing clones over the water-depth gradient. Competition for light is influenced by canopy height and foliage distribution of the competing clones. On the other hand, root and rhizome mass and length may determine the utilization of nutrient resources in the soil.

Several direct effects of water depth on individual plant growth were found. In addition, it is suggested that the susceptibility to physical and chemical stresses increases if plants are growing in deeper water. Factors that may affect the performance of helophytes at permanently inundated locations negatively are wave exposure (Coops et al., 1994), low redox conditions in the sediment due to a high organic matter content (Brock et al., 1987; Van den Brink et al., 1995), and low internal oxygen availability (Yamasaki and Tange, 1981). 
In conclusion, morphological characteristics and biomass distribution within plants shift along the water-depth gradient. Differences in the degree of plastic adjustment of morphological traits are greatest at the family level. The responses seem to be related to the zonation of the species along the water-depth gradient: $S$. lacustris in relatively deep water, Phragmites australis and S. maritimus at middle elevations, and Phalaris arundinacea in shallower water.

\section{Acknowledgements}

The support to this study by Rijkswaterstaat, Directie Zuid Holland, is gratefully acknowledged. We wish to thank Peter Boekestein, Edwin de Baat, Noël Geilen, Yvonne Godefroij, Ton Visser, Yvonne van der Waaij and the Meetdienst Zuid Holland for assistance during fieldwork and experiments.

\section{References}

Armstrong, W., 1979. Aeration in higher plants. Adv. Bot. Res., 7: 226-332.

Armstrong, W., Brändle, R. and Jackson, M.B., 1994. Mechanisms of flood tolerance in plants. Acta Bot. Neerl., 43: 307-358.

Bartley, M.R. and Spence, D.H.N., 1987. Dormancy and propagation in helophytes and hydrophytes. Arch. Hydrobiol. Beih., Ergeb. Limnol., 27: 139-155.

Brändle, R. and Crawford, R.M.M., 1987. Rhizome anoxia tolerance and habitat specialization in wetland plants. In: R.M.M. Crawford (Editor), Plant Life in Aquatic and Amphibious Habitats. Blackwell, Oxford, pp. $397-410$.

Brock, T.C.M., Van der Velde, G. and Van de Steeg, H.M., 1987. The effects of extreme water level fluctuations on the wetland vegetation of a nymphaeid-dominated oxbow lake in The Netherlands. Arch. Hydrobiol. Beih., Ergeb. Limnol., 27: 57-73.

Buttery, B.R. and Lambert, J.M., 1965. Competition between Glyceria maxima and Phragmites communis, I. The competition mechanism. J. Ecol., 53: 163-181.

Coops, H. and Smit, H., 1991. Effects of various water depths on Scirpus maritimus L.: Field and experimental observations. Verh. Ver. Int. Limnol., 24: 2706-2710.

Coops, H., Geilen, N. and Van, der Velde, G., 1994. Distribution and growth of the helophyte species Phragmites australis and Scirpus lacustris in water depth gradients in relation to wave exposure. Aquat. Bot., 48: 273-284.

Grace, J.B., 1987. The impact of preemption on the zonation of two Typha species along lakeshores. Ecol. Monogr., 57: 283-303.

Grace, J.B. and Wetzel, R.G., 1981. Habitat partitioning and competitive displacement in cattails (Typha): experimental field studies. Am. Nat., 118: $463-474$.

Haslam, S.M., 1970. The performance of Phragmites communis Trin. in relation to water-supply. Ann. Bot., 34: $867-877$.

Hejný, S. and Hroudová, Z., 1987. Plant adaptations to shallow water habitats. Arch. Hydrobiol., Ergeb. Limnol., 27: 157-166.

Hultgren, A.B.C., 1989. Growth in length of shoots of Carex rostrata Stokes in relation to water level. Aquat. Bot., 34: 353-365.

Justin, S.H.F.W. and Armstrong, W., 1987. The anatomical characteristics of roots and plant response to soil flooding. New Phytol., 106: 465-495.

Lefor, M.W., 1987. Phalaris arundinacea L.- Reed Canarygrass as a hydrophyte in Essex. Environ. Monit., 11: $771-773$. 
Lieffers, V.J. and Shay, J.M., 1981. The effects of water level on the growth and reproduction of Scirpus maritimus var. paludosus. Can. J. Bot., 59: 118-121.

McKee, K.L., Mendelssohn, I.A. and Burdick, D.M., 1989. Effect of long-term flooding on root metabolic response in five freshwater marsh plant species. Can. J. Bot., 67: 3446-3452.

Rodewald-Rudescu, L., 1974. Das Schilfrohr, Phragmites communis Trinius. Binnengewässer, 27: 1-302.

Seidel, K., 1955. Die Flechtbinse, Scirpus lacustris L. Binnengewässer, 21: 1-216.

Spence, D.H.N., 1982. The zonation of freshwater plants. Adv. Ecol. Res., 12: 37-125.

Squires, L. and Van der Valk, A.G., 1992. Water-depth tolerances of the dominant emergent macrophytes in Delta Marsh. Can. J. Bot., 70: 1860-1867.

Steinmann, F. and Brändle, R., 1984. Carbohydrate and protein metabolism in the rhizomes of Scirpus lacustris L. Aquat. Bot., 19: 53-63.

Van den Brink, F.W.B., Van der Velde, G., Bosman, W.W. and Coops, H., 1995. Effects of substrate parameters on growth responses of eight helophyte species in relation to flooding. Aquat. Bot., 50: 79-97.

Van der Valk, A.G. and Welling, C.H., 1988. The development of zonation in freshwater wetlands: an experimental approach. In: J.H. During, M.J.A. Werger and H.J. Willems (Editors), Diversity and Pattern in Plant Communities. Acad. Publ., The Hague, pp. 145-158.

Waters, I. and Shay, J.M., 1990. A field study of the morphometric response of Typha glauca shoots to a water depth gradient. Can. J. Bot., 68: 2339-2343.

Waters, I. and Shay, J.M., 1992. Effect of water depth on population parameters of a Typha glauca stand. Can. J. Bot., 70: 349-351.

Yamasaki, S. and Tange, I., 1981. Growth responses of Zizania latifolia, Phragmites australis and Miscanthus sacchariflorus to varying inundation. Aquat. Bot., 10: 229-239. 